\title{
O feminismo não é entregue de bandeja: saberes e práticas de um Coletivo feminista estudantil
}

\author{
Vanessa Soares de Castro' (i) 0000-0001-9320-3605 \\ Adriane Roso ${ }^{2}$ (i) 0000-0001-7471-133X \\ Camila dos Santos Gonçalves ${ }^{3}$ (iD) 0000-0002-0655-8895 \\ 'Instituto Federal de Educação, Ciências e Tecnologia do Rio Grande do Sul, Ibirubá, \\ RS, Brasil. 98200-000 - assistencia.estudantil@ibiruba.ifrs.edu.br \\ 2Universidade Federal de Santa Maria, Centro de Ciências Sociais e Humanas, \\ Santa Maria, RS, Brasil. 97105-900 - ccsh@ufsm.br \\ ${ }^{3}$ Pesquisadora independente, Santa Maria, RS, Brasil. 97010-491.
}

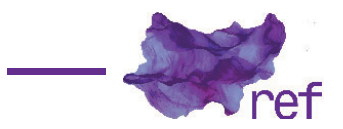

Resumo: Neste artigo, discutimos os saberes e práticas produzidos por um Coletivo feminista de estudantes de Ensino Médio de uma instituição de educação localizada no sul do Brasil. A partir da Teoria das Representações Sociais e dos Estudos Feministas e de Gênero, buscamos entender como - Coletivo se vincula aos conceitos feministas e os coloca em uso ao perseguir seus objetivos. Foi realizada uma pesquisa participante, acompanhando o Coletivo por meio da construção de um diário de campo, de um encontro de sistematização de experiências e de análise documental. Ao analisar o material produzido, organizamos três principais campos culturais: sororidade, corpos e sexualidades, e 'ser' mulher/'ser' feminista. Concluímos que as jovens buscam visibilizar e modificar as relações sociais em seu meio, elaborando saberes feministas particulares, marcados pela busca ativa e pelo conflito. Palavras-chave: movimentos feministas; representações sociais; escola; jovens.

Feminism Is Not Handed on a Silver Platter: Knowledge and Practices of a Student Feminist Collective

Abstract: In this study, we discuss the knowledge and practices produced by a feminist Collective composed by high school students in southern Brazil. Based on the Theory of Social Representations and Gender and Feminist Studies, we aim to understand how the collective is associated with feminist concepts and how it inserts them into practice as it pursues its goals. A participant study was carried out, and the activities of the Collective were monitored using field diary, an experience systematization meeting, and document analysis. The analysis of the material led to three main cultural fields: sisterhood, bodies and sexualities, and "being" a woman/"being" a feminist. We concluded that the young women elaborate on individual feminist knowledge marked by active pursuit and conflict, in order to change the social relations of their environment and render them visible.

Keywords: Feminist Movements; Social Representations; School; Youth.

El feminismo no se entrega en bandeja de plata: conocimientos y prácticas de un colectivo feminista estudiantil

Resumen: En este artículo discutimos los conocimientos y prácticas producidos por un colectivo feminista de estudiantes de una institución educativa ubicada en el sur de Brasil. A partir de la Teoría de las Representaciones Sociales y los Estudios Feministas y de Género, buscamos comprender cómo el Colectivo se vincula con los conceptos feministas y ponerlos en práctica a la hora de perseguir sus objetivos. Se realizó una investigación participante siguiendo el Colectivo mediante la construcción de un diario de campo, un encuentro para sistematizar experiencias y análisis documental. Se organizaran tres campos culturales principales: sororidad, cuerpos y sexualidades, y 'ser' mujer/'ser' feminista. Concluimos que las jóvenes participantes buscan visibilizar y modificar las relaciones sociales en su entorno mediante la elaboración de saberes feministas particulares, marcados por la búsqueda activa y el conflicto.

Palabras clave: movimientos feministas; representaciones sociales; escuela; jóvenes. 


\section{Introdução}

Neste artigo, apresentamos parte dos resultados de uma pesquisa' realizada durante os anos de 2017 e 2018 junto a um Coletivo feminista denominado Movimento Ovelhas Negras. O objetivo geral da pesquisa foi compreender as interconexões entre os sentidos do feminismo circulantes no Coletivo participante e as formas como suas integrantes buscam promover mudanças no cotidiano escolar. Neste artigo, temos como objetivo entender como as jovens participantes se vinculam aos conceitos feministas aos quais têm acesso e como os colocam em uso ao perseguir seus objetivos enquanto Coletivo.

O Coletivo Ovelhas Negras atua em um campus de uma Instituição Federal de Educação (IFE) localizada no interior do Rio Grande do Sul, sendo formado majoritariamente por estudantes do Ensino Médio Integrado, modalidade formal de educação em que o Ensino Médio regular é realizado de forma integrada e inseparável de uma formação profissional de nível técnico. O campus no qual a pesquisa foi realizada está localizado em um município com cerca de 20 mil habitantes, em uma microrregião economicamente próspera do estado, marcada fortemente pela atividade agrícola, principalmente pela produção de soja. O campus iniciou suas atividades no ano de 2010, e hoje conta com dez cursos em atividade, em diferentes modalidades - Ensino Técnico Integrado ao Ensino Médio, Ensino Técnico Subsequente ao Ensino Médio, Ensino Superior e Pós-Graduação Lato Sensu. Possui cerca de 1.200 estudantes e 120 servidores. Este é o contexto para o qual o Coletivo de estudantes em foco nesta pesquisa trouxe à tona o feminismo como tema de discussão.

As expressões dos movimentos feministas ao longo da história têm sido representadas em termos de 'ondas' definidas a posteriori, se desenvolvendo em ciclos que alternam cumes de ascensão e períodos de relativa 'dormência' (Jane PILCHER; Imelda WHELEHAN, 2004; Eliane GONÇALVES, 2016). No contexto brasileiro, seus primórdios situam-se nos anos de 1970, durante a denominada 'segunda onda' que, naquele momento, era protagonizada pelas mulheres nos países europeus e nos Estados Unidos. Apesar do alcance reduzido devido ao contexto ditatorial militar (1964-1985), no final dos anos 1980 e durante os anos 1990, com a transição para a democracia, o movimento feminista brasileiro adquiriu caráter heterogêneo e passou a se institucionalizar em diferentes partidos políticos e governos. Como consequência, o termo gênero e os debates sobre as 'questões das mulheres' passaram a fazer parte do vocabulário de políticas públicas nacionais e internacionais, o que, inclusive gerou o diagnóstico de que teria sido cooptado, esvaziado de sua dimensão política (Sonia ALVAREZ, 2014). Obviamente, o termo 'onda' para se referir aos feminismos não deve ser usado acriticamente, já que suas conquistas não são restritas a estes períodos, bem como não existe homogeneidade entre os diferentes feminismos e suas protagonistas em cada 'onda'.

Entendemos o Coletivo participante da investigação como fazendo parte de um amplo processo de expansão dos feminismos na atualidade, até mesmo em direção a cidades de pequeno porte. Em entrevista à Revista Época, a historiadora Margareth Rago afirmou, com otimismo, que "o feminismo está na moda, virou pop" (Sergio GARCIA, 2015). De fato, os diversos feminismos ganharam destaque no Brasil nos anos 2010, tendo seu ponto alto em 2015 (Dulcilia BUITONI; Martha LOPES, 2018), com a chamada 'Primavera das Mulheres' - termo criado pela mídia para se referir aos protestos contra a aprovação do PL 5069/2013, que limita o atendimento às mulheres vítimas de violência sexual no sistema público de saúde (Priscilla BRITO, 2017).

A visibilidade e o espalhamento dos feminismos nos diversos espaços sociais nestes últimos anos se deram, principalmente, por meio das redes sociais, como Facebook, Twitter, Instagram e outras. São diversos os exemplos de campanhas, projetos, páginas on-line, entre outras expressões por meio das quais os feminismos foram ganhando destaque na internet, se multiplicando também nas mídias tradicionais e no cotidiano das pessoas. Movimentos como a Marcha das Vadias (Gleidiane FERREIRA, 2013), que dividiu espaço com mobilizações como a Marcha das Margaridas no Brasil e o Ni Una a Menos na Argentina (BRITO, 2017), e campanhas como a \#PrimeiroAssedio (Rose SANTINI; Camyla TERRA; Alda ALMEIDA, 2017) são apenas alguns dos projetos feministas visibilizados pelas redes sociais que se destacaram nos últimos anos. O feminismo também se mostrou presente dentro das escolas, especialmente no contexto da chamada Primavera Secundarista, movimento de ocupação das escolas por estudantes, iniciado em 2015, no estado de São Paulo, mas que se espalhou Brasil afora (Danielly REAL, 2018).

Por meio da internet, esses grupos entram em contato com grande número de pessoas, fomentam discussões e alcançam espaços sociais diversos, em uma velocidade e de uma maneira que seriam impensáveis décadas atrás. Esse espalhamento se mostra profícuo no sentido de fazer as ideias e práticas feministas alcançarem cada vez mais sujeitos, ao mesmo

\footnotetext{
' Este artigo é oriundo de uma pesquisa de mestrado vinculada ao Programa de Pós-Graduação em Psicologia da Universidade Federal de Santa Maria (UFSM) e integra o projeto guarda-chuva Vidas Precárias no Cibermundo Estudos Sobre Violências, Poder e Interseccionalidades nos Sistemas Hierárquicos. A pesquisa teve apoio do Instituto Federal de Educação, Ciência e Tecnologia do Rio Grande do Sul (IFRS).
} 
tempo em que também apresenta riscos, especialmente o de esvaziamento de suas pautas pela dinâmica, muitas vezes, apressada, das redes sociais (Djamila RIBEIRO, 2017), e o de mercantilização e transformação em um produto a ser vendido e consumido individualmente, como um estilo de vida, destituído de seu caráter político (bell hooks, 2019a; 2019b).

Nesse sentido, concordamos com Alvarez (2014) quando a autora descreve os feminismos como campos discursivos de ação, formados por atoras/es diversas/os, desde grupos estruturados e Organizações Não Governamentais (ONGS), até agrupamentos informais, que compõem redes comunicativas onde existem visões de mundo compartilhadas, mas também tomam forma disputas de sentidos e de representações, com os sujeitos negociando significados entre si, bem como para si mesmos. A autora entende que o feminismo se encontra em um momento de "sidestreaming" (ALVAREZ, 2014, p. 17), perpassando de forma horizontal diversos setores da sociedade, resultando na multiplicação dos campos feministas. Ou seja, este não é um campo homogêneo. Os feminismos são parte de um movimento plural e coletivo, mediado por aproximações e conflitos não verticalizados, onde "seus sujeitos podem falar por ele sem credenciais, sem vinculações, 'sem carteirinha'” (GONÇALVES, 2016, p. 246).

Por isso, os termos usados nos diversos feminismos não são estáticos, nem são definidos de forma consensual e indiscutível. Diferentes contextos podem ter diversos efeitos sobre os debates feministas, incentivando certas expressões e práticas e limitando ou reprimindo outras (ALVAREZ, 2014). O campo feminista se multiplica, pois há muitas pessoas ainda se identificando com ele, vendo sua necessidade. Essa multiplicação, no entanto, não é apenas uma repetição, incorporando as singularidades dos novos sujeitos (GONÇALVES; Fátima FREITAS; Elismênnia OLIVEIRA, 2013). O chamado 'feminismo jovem' tem se mostrado extremamente heterogêneo e plural, espaço onde circulam as "contradições e conflitos que caracterizam o campo feminista mais amplo" (ALVAREZ, 2014, p. 41), integrando tanto suas potencialidades insubmissas e transformadoras quanto sua versão ajustada ao discurso neoliberal e de empoderamento individual. Os feminismos estudantis, mesmo com suas peculiaridades concernentes ao ambiente escolar, também fazem parte desse campo e apresentam essa heterogeneidade. É para as jovens estudantes que nossa atenção está voltada no momento. Como afirma Guacira Lopes Louro (1997), "as crianças e jovens escapam, certamente, aos controles de qualquer discurso - escolar ou não - que se pretenda único ou homogeneizador" (p. 137), indo além da visão corrente que as encerra em estereótipos de imaturidade, irresponsabilidade e inexperiência.

Buscamos a contribuição teórica da Teoria das Representações Sociais (TRS) para entendermos as relações que as jovens estabelecem com os conceitos feministas com os quais entram em contato, que circulam em seu meio, e de que forma os colocam em uso na elaboração de seu pensamento e de sua prática feminista. A TRS aborda o conhecimento como algo que os sujeitos sociais - pessoas e grupos - constroem em inter-relação com seu universo social e cultural, inter-relação essa que constrói também a própria realidade (Angela ARRUDA, 2002). Ela coloca em perspectiva as relações micro e macrossociais, tensionando-as (Ivana MARKOVÁ, 2017). As Representações Sociais (RS) estão no plano do senso comum, e são fenômenos que não apenas representam o mundo simbolicamente, mas também proporcionam ações, permitindo a inteligibilidade do mundo social pelos seres humanos, bem como a transformação deste mundo (Pedrinho GUARESCHI, 2010). Ou seja, as RS não estão apenas na comunicação, mas também nas práticas, as quais colocam em ação os saberes dos grupos ao agir sobre o mundo.

As Representações Sociais são formadas a partir de dois processos fundamentais: a objetivação e a ancoragem. A objetivação "permite tornar real um esquema conceitual e substituir uma imagem por sua contrapartida material" (Serge MOSCOVICl, 2012, p. 100). Este processo ocorre como um movimento de três passos (ARRUDA, 2002), que inicia com a seleção e descontextualização de elementos do que será representado, de modo a reduzir o excesso de informação, fazendo cortes no objeto com base nas informações prévias, experiências e valores dos sujeitos sociais. Estes cortes são re-costurados, e passam a formar o cerne da representação, que pode ser vista, então, como algo objetivo, palpável; a representação criada é, por fim, naturalizada, cristalizada, e passa a ser tratada como algo tangível (ARRUDA, 2002). Assim, as ideias tomam forma, não são mais constructos intelectuais de alguns sujeitos, mas passam a ser percebidas como matéria, coisas quase palpáveis e físicas presentes no mundo exterior (MOSCOVICl, 2012).

Quanto à ancoragem, é o processo pelo qual algo estranho, intrigante, é inserido em um sistema de classificações conhecido e passa a ser menos incômodo, fazendo parte do cotidiano ( $M O S C O V I C l, 2015)$. Ao entrar em contato com o que é novo, as pessoas enraízam o novo ao território do conhecido, associam o desconhecido a objetos já familiares, passando, então, a adotá-los ou rejeitá-los, apropriando-se deles, usando-os como instrumentos (MOSCOVICl, 2012; ARRUDA, 2002).

Estando a realidade sempre em transformação, também as RS serão dinâmicas e móveis, na medida em que tentam elaborar e compreender o mundo. O pensamento natural inclui não só o objeto sobre o qual se fala, mas também as relações interpessoais e grupais, a comunicação 
coletiva e/ou individual, as identidades e interesses dos atores, o uso de julgamentos e valores socioculturais, as representações historicamente consolidadas (Sandra JOVCHELOVITCH, 2014). Como formas sociais de conhecimento, as RS seguem as necessidades e desejos dos grupos, alterando o objeto à medida do que for preciso, de modo que os grupos sociais imprimem suas próprias marcas ao representarem o mundo. Os sujeitos fazem distorções para adaptar os objetos aos seus interesses, subtraem elementos de difícil assimilação, e incorporam conotações ou atributos a partir de seu envolvimento com o objeto (ARRUDA, 2002). O interessante é observar como estas modificações ocorrem, "o que elas indicam, e como elas constituem a representação, dando-Ihe um sentido de verdade e uma eficácia simbólica" (ARRUDA, 2002, p. 139).

Assim, a partir dos conceitos de ancoragem e objetivação, a teoria nos auxilia na compreensão dos processos de construção do feminismo do Coletivo Ovelhas Negras e de como as jovens se localizam (intencionalmente ou não) no campo feminista. Consideramos que, para melhor compreender os fenômenos sociais, é preciso observar como estes estão imbricados com os contextos nos quais tomam forma, com um olhar que nos permita visualizar as singularidades e as diversas possibilidades que estes fenômenos podem adquirir. Por isso, consideramos importante que sejam visibilizados casos específicos como o do Coletivo Ovelhas Negras, que podem ajudar a compreender as diferentes maneiras como o feminismo tem sido visto e colocado em prática pelas jovens na contemporaneidade.

\section{Caracterização do Coletivo interlocutor}

O Coletivo participante desta pesquisa se autodenomina Movimento Ovelhas Negras. Ele foi formado em 2016 por um grupo de estudantes de uma turma de $3^{a}$ ano do Ensino Médio Integrado de uma Instituição Federal de Educação. O Coletivo é formado apenas por estudantes mulheres, contando com homens como apoiadores e participantes externos. Em sua maioria, estas jovens são brancas (apenas uma integrante se declara negra), de classe média, moradoras da área urbana e central de um município marcadamente rural. A aproximação física com o Coletivo foi feita pela primeira autora, que atua como psicóloga na instituição em que o Ovelhas Negras foi criado. Este contato é anterior à pesquisa, ocorrendo por meio da parceria na realização de atividades que abordam feminismo e relações de gênero na escola. A movimentação das jovens fez eco às inquietações da autora sobre o ressurgimento do feminismo na atualidade, o que levou à decisão de eleger o Coletivo como objeto de estudo. As estudantes se mostraram dispostas a participar do processo de pesquisa.

As dinâmicas que atravessaram esse percurso são complexas e desafiadoras. Enquanto autoras feministas, valorizamos nossa implicação no contexto de investigação. Junto às participantes, foram realizadas constantes reflexões éticas sobre a relação pesquisadora/ psicóloga-participantes. Com a equipe de pesquisa, pensamos sobre os enquadramentos da pesquisa, sobre o fazer ciência no Brasil, questionando antinomias como neutralidade/ objetividade, sujeito/assujeitamento, minoria/maioria. A modalidade de pesquisa participante é propícia a esta epistemologia feminista, haja vista que ela possibilita que o percurso seja coconstruído no caminhar da investigação, abrindo espaço para colocar os diferentes cruzamentos de opressões e injustiças vividas por essas jovens mulheres.

A pesquisa acompanhou o Coletivo ao longo dos anos 2017 e 2018. Participaram da pesquisa 17 estudantes com idades entre 15 e 20 anos, sendo 12 ativas no Coletivo no momento da pesquisa e cinco que fizeram parte de sua criação, mas que já não participavam mais de suas atividades. Para nos referirmos ao Coletivo e às suas integrantes, optamos por usar os termos que elas mesmas utilizam. Elas referem a si mesmas como o Coletivo, ou o Ovelhas Negras, ou as Ovelhas, já que consideram que cada integrante é uma 'ovelha negra' - como referência ao ditado popular ilustrado na música de Rita Lee que faz referência à "ovelha negra da família", aquela que se distingue das demais, do restante do 'rebanho'.

\section{Procedimentos de pesquisa}

A pesquisa teve cunho qualitativo, tendo sido delineada a partir da pesquisa participante. Carlos Rodrigues Brandão (2006) aponta a pesquisa participante como sendo um meio de conhecer as questões sociais a serem trabalhadas, um instrumento de aprendizado dialógico, parte de um processo mais amplo de construção de um saber popular, e parte da trajetória de empoderamento dos movimentos sociais, juntamente com a educação popular. Em uma investigação com esse caráter, é importante que se construam procedimentos que permitam o diálogo, criando espaço para o debate (Maria SILVA, 2006).

A pesquisa foi desenvolvida por meio de diferentes métodos (aproximação ao campo, diário de campo, encontro de sistematização de experiências), que buscaram tanto gerar informações sobre o campo pesquisado quanto colaborar com o Coletivo participante por 
meio do registro e da historicização do percurso. Um desses métodos foi a proposição de um momento de sistematização de experiências, a partir da proposta de Oscar Jara Holliday (2006). Esse processo permite a compreensão da experiência para melhorar a prática, possibilita 0 compartilhamento das experiências e ensinamentos do Coletivo/grupo em questão com outros coletivos/grupos, e enriquece o debate teórico, oferecendo diálogo entre teoria e prática (HOLLIDAY, 2006). Para realizar esta sistematização, foi proposto um encontro voluntário com as integrantes atuais e egressas do Coletivo para recuperar a história das experiências do grupo, ordenando seus elementos, como aconteceram, e como foram vividos e percebidos pelo Coletivo. A partir daí, buscou-se interpretar as causas do que ocorreu a fundo, o que levou a história do grupo a acontecer desta maneira, e quais as raízes e as consequências desses fenômenos. Este encontro foi gravado e transcrito.

No entanto, o principal método de aproximação com o campo foi a participação da primeira autora nas reuniões, encontros e ações promovidas pelo Coletivo, dando ênfase à observação dos acontecimentos, ações, reações, diálogos, interações que acontecem no cotidiano do Coletivo. As observações deste percurso foram registradas em diário de campo, contendo também imagens, fotografias, e alguns escritos das participantes, registrados com autorização das mesmas. Na medida do possível, foram realizadas anotações pela autora durante a observação e participação nas atividades, principalmente para que as falas específicas, os diálogos e a ordem dos acontecimentos, elementos tão passíveis de sofrer com as limitações da memória, pudessem ser propriamente registrados. O diário de campo foi partilhado com a equipe de pesquisa, de modo que pudessem ser observadas lacunas, pensar elementos que precisaram ser ainda observados e investigados e realizar interpretações provisórias.

Entendemos o diário de campo como um escrito do momento, inicialmente espontâneo e parcial, mas que, ao ser relido posteriormente, permite a reflexão crítica sobre a prática realizada (Remi HESS, 2006). Ao mesmo tempo, aprendemos com a tradição etnográfica que o diário de campo, justamente por ser construído a partir de um lugar situado, forma um relato que não é o reflexo fiel da realidade, sendo também um trabalho interpretativo que busca dar sentido ao que é observado, vivenciado e registrado (Clifford GEERTZ, 2008). Assim, nossa leitura do campo é limitada e localizada, sendo uma leitura possível, mas não definitiva.

Para a interpretação das informações de pesquisa, foi feita uma leitura flutuante e préanálise do diário de campo com a identificação de algumas "categorias", ainda amplas, flexíveis e inacabadas, de onde surgiram "hipóteses interpretativas" (ARRUDA, 2014, p. 137), delineadas ao longo da leitura do material disponível. A partir destas hipóteses interpretativas e de novos aprofundamentos nas teorias que embasaram a pesquisa, elaboramos campos culturais. Os campos culturais carregam significados amplos, conceituais e contextuais, e trazem também as especificidades locais, bem como as relações de poder presentes no campo (Adriane ROSO, 2009). Ou seja, eles nos ajudam a pensar os diferentes significados que permeiam o objeto de pesquisa, tendo em vista, simultaneamente, nossas teorias de base e o terreno cultural, histórico e social em que as pesquisadoras e participantes estão imersas.

\section{Resultados e Discussão}

Apesar de observarmos as redes sociais como espaço importante para os movimentos feministas na atualidade, e tendo tido grande importância para que as Ovelhas Negras entrassem em contato com a existência do feminismo, a atuação deste Coletivo se deu basicamente de forma direta, dentro do espaço escolar. Existem páginas do Ovelhas Negras no Instagram e no Facebook, mas elas apresentam pouca atividade, de modo que observamos suas representações sociais dos feminismos a partir de suas ações, falas, cartazes, escritos, entre outros. É a partir destas manifestações que apreendemos alguns dos campos culturais mais salientes no feminismo das Ovelhas Negras: a sororidade, o corpo/sexualidade, e o 'ser' mulher/'ser' feminista. Esses temas não abrangem a totalidade dos saberes e das práticas construídos pelas estudantes, sendo possível que outros pontos relevantes para o Coletivo não tenham sido abordados em nossas análises. Entretanto, acreditamos que os três campos culturais que escolhemos possibilitam um vislumbre das pautas mais presentes no ativismo do Coletivo participante, sendo a confiança das jovens na justeza de abordar esses temas seu principal motivo para existir enquanto coletivo.

\section{Descobrir-se na sororidade}

Um dos objetivos principais da formação do Coletivo Ovelhas Negras pelas jovens estudantes foi a busca pela união das mulheres em seu cotidiano, sendo o termo sororidade um dos primeiros usados pelo grupo. Suely Costa (2009) explica que a palavra sororidade é usada pelos movimentos sociais feministas para simbolizar a identificação entre as mulheres, considerando que estas compartilham sentimentos e sensibilidades, tendo como base experiências biológicas que seriam 'iguais' para todas, unindo mulheres diferentes em torno 
de lutas comuns, como por direitos reprodutivos e contra a violência doméstica. A sororidade simboliza a solidariedade nas relações entre mulheres, se fazendo presente em processos de cuidado e ajuda mútua, bem como nas ações políticas que visam provocar a tomada de consciência, ajudando a construir uma imagem coletiva de mulher (COSTA, 2009).

A primeira ação do Coletivo Ovelhas Negras, realizada em 2016, consistiu na colocação de caixinhas para compartilhamento de absorventes nos banheiros para mulheres da escola. Em uma pequena placa que acompanhava as caixinhas, as estudantes estimulavam outras mulheres a colaborar com a ação e propunham a seguinte definição de sororidade: "diminuir a rivalidade feminina; não oferecer crítica, mas sim apoio; ao invés de competir, andar juntas; irmandade". A visão de sororidade expressa pelas Ovelhas Negras apresenta esse conceito enquanto um oposto à 'rivalidade feminina'. O termo sororidade esteve em seu discurso em outros momentos, ainda com o mesmo sentido, como retrata este trecho do diário de campo:

\begin{abstract}
A. falou sobre a questão da sororidade, de como é um assunto que ela acha que precisa ser bastante abordado. Disse que por mais que já faça parte do Coletivo e já se diga feminista desde o ano passado, foi só neste ano que começou a ver em si mesma a questão da "rivalidade feminina", de como reproduzia isso, e começou a tentar mudar (Diário de campo, registro do dia 01/10/2018, p. 67).
\end{abstract}

A definição de sororidade das jovens coloca em contraponto crítica e apoio, competição e 'andar juntas', propondo que o termo seja o correspondente antinômico da 'rivalidade feminina'. Antinomias como esta são um modo como as representações sociais tomam forma. Certas categorias são usadas em função de sua relação com uma categoria oposta, em geral classificando o que está de acordo com as normas de um certo grupo e o que vai contra essas normas (Christian STAERKLÉ; Alain CLÉMENCE; Dario SPINI, 201 1). É isso que podemos acompanhar na construção da concepção de sororidade das Ovelhas Negras. Sua principal preocupação ao usar o termo é oferecer uma alternativa à rivalidade feminina, modificar a forma como entendem que as mulheres são ensinadas a competir entre si para obter a atenção dos homens, criticando, humilhando e julgando umas às outras nesse processo. Esse uso do termo sororidade é um recorte que elas fazem dele, 'desmembrando-o' e ancorando-o à sua necessidade de encontrar uma resolução para as disputas nas relações entre mulheres no cotidiano da escola e das relações interpessoais, como fofocas, desentendimentos, inimizades, formação de grupos fechados, entre outras dinâmicas que ocorrem no ambiente da escola.

A sororidade surge, então, como possível solução a esta problemática, como um potencial agregador que teria o condão de, ao ser trazido à tona, proporcionar a união entre as jovens. Esta representação do termo sororidade é objetivada na forma de construções imagéticas e simbólicas, como a própria colocação de caixinhas para compartilhamento de absorventes (estratégia que, inclusive, obteve pouco engajamento, sendo mais comum encontrar as caixas vazias do que contendo algum item) e a colocação de cartazes na escola com frases como "Não me elogie insultando outra mulher" e "Seja uma mulher que levanta outras mulheres", frases que estimulariam esse potencial de união, colocando para funcionar as 'engrenagens' da sororidade. É difícil verificar em que medida estas ações têm efeitos práticos na resolução dos conflitos entre as jovens, especialmente no cenário escolar, em que as/os jovens se dividem entre si em função de identificações com temas/estéticas/hábitos em comum, e em que, inclusive, a presença de um coletivo feminista evidencia a formação de grupos pró e contra o feminismo na escola. Como é possível romper a barreira que distancia outras jovens do feminismo e da própria noção de sororidade?

Ao apostar apenas no caráter simbólico de sororidade, as jovens muitas vezes deixam de atentar para a natureza prática que o termo carrega (ou deveria carregar), ou seja, para as práticas com potencial de promover uma união de fato entre mulheres. O próprio Coletivo promove ações nesse sentido, como momentos de compartilhamento e de escuta mútua. Ao mesmo tempo, também deixa de voltar sua atenção para os limites da aplicação do conceito, não trazendo à tona questões imprescindíveis: o que fazer quando a sororidade se mostra insuficiente para resolver as discordâncias entre mulheres? Deve-se sempre concordar com uma mulher, apenas pelo fato de ela ser mulher, mesmo quando ela está reforçando desigualdades? O que fazer quando se falha em prestar apoio ou até mesmo em enxergar a dor de outra mulher, por questões que vão além do gênero, como quando há questões raciais, de classe ou de sexualidade envolvidas?

Nesse sentido, o uso que as jovens fazem do termo deixa escapar alguns pontos importantes e que perpassam a relação entre as mulheres reais. Como nos mostram Pilcher e Whelehan (2004), o conceito de sororidade, por mais que tenha servido para mobilizar mulheres ao longo do tempo, não foi suficiente para assegurar direitos iguais a todas, se mostrando insuficiente para dar visibilidade às diferenças existentes entre as mulheres. Diversas autoras entenderam que o uso da palavra oculta as relações de poder e dominação presentes nas relações entre mulheres, o que o fez alvo de críticas (COSTA, 2009). Este é um problema presente 
no Coletivo foco de nossa pesquisa, particularmente se considerarmos que se trata de um grupo criado e formado principalmente por jovens brancas de classe média.

Em contraponto, bell hooks (2019a; 2019b) reconhece as críticas à noção de sororidade, e o quanto o termo por si só não garante que as mulheres irão lutar lado a lado. Nesse sentido, a autora entende que é preciso rejeitar a sororidade baseada em uma ideia superficial de união, bem como a sororidade que dita que as mulheres devem se amar e se apoiar incondicionalmente, sempre evitando o conflito e o desacordo, o que não significa que ele deva ser jogado fora. hooks (2019a) sustenta que ele deve ser renovado, olhado a partir da caminhada que foi feita desde que o conceito começou a ser usado, para que faça sentido ao ser posto em relação com o corpo teórico feminista contemporâneo. Para a autora, a força da sororidade está em permitir a formação de laços entre mulheres para proteger seus interesses, sendo uma solidariedade política, que só é possível quando as mulheres buscam reconhecer e deixar de usar seus privilégios raciais e de classe para estabelecer relações de dominação com outras mulheres. hooks alerta para a importância da apropriação do termo pelas feministas mais jovens, pois ele continua sendo poderoso.

Esse potencial da ideia de sororidade já foi visto pelas Ovelhas Negras, estando o termo presente na raiz do Coletivo. Ao conjurar o termo e aplicá-lo a problemas reais de sua vivência escolar, as jovens demonstram buscar se aliar não a um feminismo individualista que reforça o sucesso por meio da competitividade e vende o ideal da "'mulher empoderada e livre'" (Fernanda MEDEIROS, 2017, p. 160), mas sim à busca da solidariedade e da coletividade, ou seja, ao "empoderamento comunitário" (ROSO; Moisés ROMANINI, 2014, p. 84). Buscam compartilhar com as demais o que aprenderam com o feminismo, e usar esse conhecimento para dar conta de questões que as tocam intimamente, demonstrando um rompimento com o pensamento majoritário que valoriza a competição em detrimento da cooperação, principalmente nas relações entre mulheres. Entretanto, para que sua proposta de sororidade possa, de fato, alcançar a todas, como é seu objetivo, precisa identificar suas limitações, se abrir ao reconhecimento das diferenças entre as próprias mulheres, e se colocar enquanto prática no cotidiano.

\section{Controle dos corpos e das sexualidades}

A pauta em torno do controle dos corpos e da sexualidade das mulheres está bastante presente no Coletivo Ovelhas Negras e foi expressa no Ato Contra a Cultura do Estupro que suas fundadoras realizaram em 2016, no início da trajetória do Coletivo, em solidariedade a um caso de estupro coletivo sofrido por uma jovem de 16 anos na cidade do Rio de Janeiro e que foi bastante veiculado nas mídias sociais e tradicionais, fazendo o tema da cultura do estupro ser trazido à tona no discurso público. Renata Sousa (2017) explica que a expressão 'cultura do estupro' se refere a como a violência sexual é naturalizada a partir de uma série de ensinamentos sociais, que ditam como as mulheres devem se relacionar não só com sua própria sexualidade, mas como devem ser suas condutas, sua forma de se vestir, que lugares devem frequentar (ou não), como devem se relacionar com os homens, pois esses e outros fatores fazem com que elas sejam mais ou menos culpáveis no caso de sofrerem um abuso sexual; ou seja, faz parte da cultura do estupro depositar na mulher "a responsabilidade sobre os atos dos terceiros contra a sua integridade sexual" (SOUSA, 2017, p. 13). Ao mesmo tempo, também é ensinado aos homens que eles têm o direito de ter livre acesso ao corpo da mulher, devem aproveitar qualquer oportunidade para realizar o ato sexual, e não devem aceitar um 'não' como resposta (SOUSA, 2017).

A forma como a cultura do estupro foi abordada pelas jovens foi por meio da crítica ao controle de suas vestimentas, manifesto nos cartazes confeccionados por elas com as frases "Roupas NÃO estupram. Estupradores estupram. A culpa nunca é da vítima!" e "Minhas roupas não determinam meu consenso", além de outras. Sua preocupação com o controle e a vigilância sobre as roupas e o corpo das mulheres surge também em suas críticas a como o discurso da direção do campus sobre a vestimenta no ambiente escolar toma a forma de reprimendas disfarçadas de conselhos em nome do temor pela integridade física das jovens.

[...] ano passado, quando deu os negócios da Agronomia [abaixo-assinado feito pelo Coletivo contra o assédio vindo de estudantes do curso superior], e a gente chegou lá, tipo, de bermuda de educação física, legging, e tal, ela [integrante da direção da escola] falou "mas vocês tomem cuidado, também, com essas roupas de educação física quando vocês vêm". Tipo, meu, olha o que a gente tá vindo aqui discutir! Fiquei muito chateada (Registro de fala de uma participante no encontro de sistematização de experiências).

A questão da vigilância às roupas das mulheres, tão presente na educação escolar, nos remete a como se organizam as relações de poder com base em gênero. Gayle Rubin (1993) fala sobre como, na economia política do sexo, as mulheres são objeto de troca entre os homens - seja no casamento, seja como prostitutas, servas, produtos. Nesse contexto, "a sexualidade 
feminina preferida seria aquela que correspondesse ao desejo dos outros, em lugar daquela que ativamente desejasse e procurasse uma resposta" (RUBIN, 1993, p. 13). Também Pierre Bourdieu (2015) fala sobre como a submissão das mulheres nessa economia de trocas simbólicas faz com que seus desejos sejam desconsiderados, e com que precisem se submeter ao olhar dos outros, que as irá avaliar de acordo com o quanto elas atendem ou não às expectativas masculinas.

Este controle da sexualidade e do corpo das mulheres vem sendo motivo de resistência e denúncia já há algum tempo, e, no caso das jovens do Coletivo, esta resistência ocorre principalmente no contexto da instituição de ensino. Louro (2003), ao falar de suas memórias escolares, lembra o controle rigoroso que era feito das saias dos uniformes, com discursos que "transitavam pelo terreno da higiene, da estética e da moral" (p. 19), e de como ela e suas colegas criavam estratégias de resistência, por exemplo, "enrolando" as meias três-quartos até a altura do tornozelo quando saíam para o recreio, ou levando uma minissaia escondida para trocar ao sair da escola. Nos anos 1960 e 1970, em países como Estados Unidos, Canadá e Austrália, jovens estudantes já propunham suas próprias políticas do corpo, lutando contra códigos de vestimenta e segregação por sexo nas escolas (Kera LOVELL, 2016). O controle das roupas e estilos de cabelos era acusado pelas jovens de tolher sua liberdade de expressão, bem como o uso de saias curtas as impedia de se movimentar livremente e de evitar olhares invasivos dos colegas homens. Para resistir a esta normatização, elas organizavam ações individuais e coletivas, que incluíam ocupações dos escritórios de diretores e de reuniões do conselho escolar, mudanças nas vestimentas em sinal de protesto, e denúncias em cartas e textos em publicações feministas (LOVELL, 2016).

No Brasil, esta pauta surgiu com grande força nas mobilizações da Marcha das Vadias, movimento criado no Canadá, em 2011 , como rechaço à fala de um policial que, durante uma palestra em uma universidade, 'orientou' que as mulheres não se vestissem como vadias se não quisessem ser estupradas (Morgani GUZZO, 2019). Campanhas como a "Vai ter shortinho, sim", realizada em 2016 por estudantes de uma escola de Porto Alegre para protestar contra normas que proibiam o uso de regatas, chinelos e, especificamente para as meninas, shorts (Marcielly MORESCO, 2016), também trouxeram à tona a questão do controle das vestimentas das jovens e de sua culpabilização no caso de abusos e assédios dentro do contexto escolar.

Em um dos cartazes elaborados e afixados na escola pelas Ovelhas Negras, lê-se a frase "Meu corpo não está aberto para debate", que afirma sua autonomia e liberdade, negando a possibilidade de que quaisquer pessoas ou instituições devam ter o poder de deliberar sobre seus corpos. Também é possível ver esse posicionamento nos cartazes produzidos por elas abordando a questão do aborto, por exemplo, com dizeres como "Meu corpo, minha lei. Legalização do aborto" e "Sem útero, sem opinião". 2 É importante ressaltar que a máxima 'meu corpo, minhas regras' enquanto política feminista não pode ser usada sem problematizações, já que traz em sua base uma retórica liberal de propriedade do corpo acima de qualquer outra coisa que precisa ser questionada, como aponta Rosalind Petchesky (2015). A autora chama atenção para como essa retórica corre o risco de servir como justificativa para reforçar políticas neoliberais, acaba borrando a barreira entre o uso do corpo como resistência ou como desespero, e escondendo a interdependência entre os corpos, que não são completamente independentes uns dos outros no momento em que estão socialmente relacionados entre si. Nesse sentido, esta lógica se mostra importante para que jovens como as participantes de nossa pesquisa e tantas outras possam reconhecer seu direito a não ter seus corpos controlados ou violados, mas também precisa ter observados os limites e os riscos de seu uso.

O que as Ovelhas Negras buscam ao afirmar a posse e a tomada de decisões sobre os próprios corpos é assumir o papel de sujeitos e romper com a dominação que as coloca como mercadorias na economia de trocas simbólicas. Além disso, desconstroem representações sociais hegemônicas, especialmente aquelas presentes na cultura do estupro, que ditam que existem formas de exercer a feminilidade que são mais culpáveis no caso de violação sexual do que outras.

A forma como o Coletivo foi se relacionando com este tema, no entanto, foi mudando ao longo do tempo. Vimos como o termo "cultura do estupro", de compreensão mais complexa, passou a desaparecer do discurso do Coletivo, enquanto o termo assédio, de leitura mais acessível, tornou-se o escolhido para abordar a questão das violências ao corpo e à sexualidade das mulheres.

Há vários exemplos do uso do termo assédio pelo Coletivo para se referir às suas demandas por respeito com relação aos seus corpos. Um deles foi a elaboração de um abaixo-assinado contra os assédios sofridos por estudantes do ensino médio por parte de estudantes do ensino superior, no qual elas denunciavam o assédio e o bullying praticado pelos estudantes mais velhos. Outras ações do Coletivo incluíram enfrentamento a colegas da turma que tiravam fotos invasivas das meninas na escola, esclarecendo a eles que o que faziam era assédio. As jovens

2 É nosso entendimento que mulheres sem útero (histerectomizadas, trans, nascidas sem útero, que não usam o útero ou outras possibilidades corpóreas) têm o direito de expressarem suas opiniões. 
também organizaram conversas sobre assédio com todas as turmas de ensino médio da escola, em uma ação alusiva ao Dia Internacional da Mulher:

Contaram que a conversa em uma das turmas começou com um menino falando que um dia ele havia sido assediado na rua por uma mulher. As meninas [...] citaram um vídeo da Jout $\mathrm{Jou}^{3}$ onde ela fala sobre como as mulheres já normalizaram tanto o fato de serem assediadas, que isso nem se torna assunto, simplesmente aprendem a viver com isso. Disseram que, para fazer esse colega estudante entender isso, falaram um pouco sobre como seria se o que ele sentiu com algo que aconteceu uma vez, acontecesse todos os dias, como acontece com as mulheres. Disseram que ele deu um bom retorno, pareceu ter pensado a respeito. Elas consideraram a fala inicial dele, por mais que problemática, positiva, por ter permitido o início do debate, a desconstrução de algumas ideias (Diário de campo, registro do dia 14/03/2018).

O trecho mostra como o contato com a pauta do assédio sexual na internet, abordado por uma mulher com a qual se identificam, foi importante para a forma como o Ovelhas Negras se relaciona com os termos do feminismo. A forma como o termo assédio, cujas origens remontam às denúncias das mulheres trabalhadoras urbanas contra condutas de homens no ambiente de trabalho na década de 1970 (Carme ALEMANY, 2009), aparece nas mídias e no conteúdo circulante no feminismo com o qual as jovens entram em contato e se identificam como o conteúdo da fala da Jout Jout - contrasta com as representações do termo cultura do estupro, termo este que ganhou notoriedade e foi apropriado pelas estudantes participantes a partir de um caso chocante de estupro coletivo. Entendemos que este aparente contraste nas representações sociais dos termos assédio e cultura do estupro pode ter sido um fator importante, que fez com que as jovens passassem a usar apenas o termo assédio para dar conta de suas demandas envolvendo o controle dos corpos e da sexualidade das mulheres em suas ações, ${ }^{4}$ enquanto o termo cultura do estupro apenas foi abordado pelo Coletivo para se referir ao Ato Contra a Cultura do Estupro citado anteriormente.

Referimo-nos ao contraste entre os termos assédio e cultura do estupro apenas como aparente, por entendermos que a naturalização dos assédios sexuais às mulheres faz parte do mecanismo de ação da cultura do estupro. Entretanto, as jovens parecem ter dedicado pouco tempo para fazer essa relação, o que pode ser visto em sua surpresa, durante a recepção às estudantes calouras, realizada em 2017, quando o tema da violência sexual propriamente dita surgiu:

A: É, daí outros relatos eram tipo em festa, sabe, tipo assim, ah, o cara chegou numa festa e, sei lá... e daí a guria que falou que já sofreu... foi violentada realmente. Daí aquilo eu fiquei... eu não sabia o que eu falava. [...] É que tu não passa por aquilo. Tu não sabe. Tipo assim, eu nunca passei por isso.

B: A gente nunca acha que é alguém próxima. Que alguém vai falar (Registro de diálogo no encontro de sistematização de experiências).

Na fala das jovens, vemos seu choque com o relato de estupro, que contrastava com os demais depoimentos de assédio que, estes sim, faziam mais parte de seu cotidiano. Assim, é possível que a expressão 'cultura do estupro' tivesse menos potencial para ser ancorada em suas práticas cotidianas do que o termo assédio sexual, já que as representações sociais em torno dele se mostram mais condizentes com a posição social e com as expectativas das jovens sobre o tipo de problema que enfrentam em seu cotidiano - cotidiano este em que elas não esperam que, de fato, um estupro possa ocorrer.

Uma das criadoras do Coletivo, egressa da instituição no período da pesquisa e idealizadora da ação contra a cultura do estupro citada anteriormente, relatou que, em seu período na escola, tinha naturalizado os assédios no campus, não tendo pensado em problematizá-los. Foram as estudantes que ingressaram no Coletivo nos anos posteriores que se encarregaram de problematizar a questão do controle das vestimentas e das atitudes assediadoras dentro da escola, aproximando a pauta do controle dos corpos e das sexualidades de suas vivências e problemáticas cotidianas. Ou seja, foi por meio do termo assédio que passaram a questionar os discursos presentes na escola sobre seus corpos, passando a nomear e enfrentar o que sentiam na pele - o que não ocorreu a partir do termo cultura do estupro, relacionado a um acontecimento aparentemente descolado de suas vivências diretas.

Sendo as integrantes do Ovelhas Negras, em sua maioria, jovens brancas, de classe média, moradoras de um contexto extremamente diferente daquele da jovem vítima de violência sexual à qual prestaram solidariedade em seu Ato Contra a Cultura do Estupro, nossa hipótese é de que realizaram um processo de ancoragem (MOSCOVICl, 2015; 2012; ARRUDA,

${ }^{3}$ Apelido de Julia Tolezano, jornalista que possui um canal na plataforma de vídeos YouTube, chamado JoutJout Prazer, onde discute temas como feminismo, relacionamentos, cultura pop, entre outros.

${ }^{4}$ Para demonstrar isso, se faz importante notar que o termo "assédio" apareceu no diário de campo 26 vezes, enquanto a palavra "estupro" apareceu quatro vezes, e o termo "cultura do estupro" apenas uma vez. Essa discrepância se nota também no encontro de sistematização de experiências, gravado e transcrito, no qual o termo "cultura do estupro" não apareceu nenhuma vez, a palavra "estupro", uma vez, e o termo "assédio" apareceu cinco vezes. 
2002) ao termo assédio que o tornou um significante mais próximo de suas vivências - e de suas leituras sobre estas vivências - do que o termo cultura do estupro. Assim, a abordagem das jovens sobre a autonomia de seus corpos, sexualidades e vestimentas, e a escolha do termo para abordar a temática, passa pelas representações sociais sobre os assuntos circulantes na mídia e nas redes sociais e por intersecções que possibilitam a aproximação/familiarização com certos termos e não com outros, como sua posição racial, de classe e etária, e suas experiências e necessidades cotidianas.

Por outro prisma, ainda que estudos sobre a violência sexual sinalizem a naturalização do estupro nas sociedades em geral, afetando mulheres de diversas camadas sociais, independente do nível educacional, da orientação sexual e marcador geracional, a escolha predominante pelo termo "assédio" não significa não se reconhecer como possível alvo desta modalidade de violência. Esta escolha, talvez inconsciente, pode estar a serviço da defesa psíquica. Queremos dizer que, ainda que as mídias ampliem o acesso aos acontecimentos de estupro, tornando-os quase onipresentes no campo fantasmático das mulheres, reduzir o uso da expressão estupro no cotidiano pode ser uma estratégia de sobrevivência, um modo de proteção, aliviando o peso da insegurança que permeia os espaços públicos e privados.

\section{'Ser' mulher e 'ser' feminista}

A visão que as Ovelhas Negras constroem sobre 'ser' mulher ${ }^{5}$ atravessa temas como a socialização familiar e a escolarização com base em gênero, e a ideia de ser feminista implica se relacionar com estes temas de forma crítica e questionadora, na busca por romper determinados padrões de dominação. As relações familiares e a socialização dos meninos e meninas é um assunto bastante presente em suas ações e conversas informais. Uma das estudantes disse atribuir muito de seu interesse pelo feminismo ao fato de ter um irmão mais novo, e de querer evitar que ele se torne machista e abusador quando crescer, o que denota seu entendimento de que a socialização dos meninos costuma levá-los a ter esse tipo de comportamentos e atitudes quando adultos. As Ovelhas Negras incluem em suas discussões muitas das divergências que encontram em suas relações familiares quando o assunto é gênero e sexualidade, sendo o Coletivo espaço para desabafar sobre essas divergências - podemos fazer a leitura de que as divergências familiares estão presentes no próprio nome do Coletivo, no qual elas se posicionam como as 'ovelhas negras', aquelas que são mal vistas pela família, o que se dá, no caso delas, por sua postura feminista, questionadora. Elas criticam a forma como as meninas são socializadas para serem recatadas, frágeis, criadas para ocupar a função de esposas e agradar ao olhar masculino.

Na sociologia, o termo socialização se refere à forma como os indivíduos conhecem a cultura da sociedade em que vivem, o que, para a discussão de gênero, se refere à forma como as pessoas aprendem a ser tornar 'masculinas' ou 'femininas' (PILCHER; WHELEHAN, 2004). As jovens participantes entendem que a forma como as mulheres são ensinadas desde a infância a se comportarem de acordo com certa noção de feminilidade e do que é considerado 'ser' mulher faz com que elas passem por limitações em suas vidas, internalizando as imposições do meio social. Esse entendimento é expresso em um cartaz do Coletivo que faz o questionamento "O que você já deixou de fazer por ser mulher?". Essa visão das estudantes pode ser relacionada com a forma como Simone de Beauvoir (1967) descreve a socialização diferenciada de meninos e meninas. A autora afirma que existe uma permissão para que as meninas saiam da infância de modo menos brutal, sem lhes retirar de forma abrupta as indulgências da infância, o que esconde um estímulo à fragilidade e docilidade; já dos meninos se exige mais, estimulando-os a não tentar agradar aos outros, ensinando-os que devem ser superiores, viris, orgulhosos. Ao chegar à adolescência, então, a jovem descrita por Beauvoir está "convencida da superioridade viril", e deseja, por meio do casamento, atingir sua "dignidade social integral" (p. 67). Podemos questionar o quanto esta forma de socialização feminina marcada pelas 'indulgências infantis' de fato representa todas as mulheres, mas parece ser condizente com as denúncias específicas das Ovelhas Negras.

A dominação masculina, na perspectiva de Bourdieu (2015), também vai cumprir um papel de socialização, produzindo corpos socialmente diferenciados. São criadas identidades masculinas e femininas, que se inscrevem na naturalização de uma ética que ensina as mulheres a se fazerem pequenas, as confina ao espaço doméstico, a uma identidade minoritária, de modo que as próprias mulheres passam a aceitar como natural essa submissão. Para o autor, essa dominação simbólica só pode ter fim com uma "transformação radical das condições sociais de produção das tendências que levam os dominados a adotar, sobre os dominantes e sobre si mesmos, o próprio ponto de vista dos dominantes" (BOURDIEU, 2015, p. 54). Assim, ao promover um debate que tenta retirar a conjugalidade do centro da vida das mulheres, bem como questionar aspectos atribuídos a certa 'feminilidade' incentivada por suas famílias desde ${ }^{5} \mathrm{O}$ verbo 'ser' compõe o discurso das participantes, ainda que, para muitas feministas, 'tornar-se' mulher designa, mais precisamente, um processo que vivenciamos, e não algo que se 'é'. 
o nascimento, o Coletivo busca uma quebra com o padrão de socialização que promove a dominação das mulheres.

Debates sobre o sexismo e o machismo na educação escolar também surgem em algumas práticas das Ovelhas Negras e fazem parte do modo como suas integrantes enxergam as imposições sociais às mulheres. Esse assunto surgiu algumas vezes, vindo principalmente de uma estudante do curso de Mecânica - curso tradicionalmente considerado 'masculino' no campus.

A. falou sobre a questão do machismo no curso técnico em Mecânica, de como não há nenhuma professora na área técnica, e de como os professores homens do curso são machistas. [...] Ela também contou da dificuldade ao procurar estágio, de como uma mulher, mãe do dono da empresa, disse que só estavam contratando homens [...] porque as mulheres não ficavam na área, já que Engenharia Mecânica não é curso para mulher. Além disso, segundo a estudante, quando a empresa contrata mulheres, é apenas em setor sem tantos homens, pois do contrário elas são assediadas - o que faz com que a empresa apenas resolva contratar menos mulheres (Diário de campo, registro do dia 01/10/2018, p. 68).

O extrato do diário de campo ilustra a visão de mulher com a qual a estudante se deparou em um curso e uma profissão que, de acordo com os ditames da divisão sexual do trabalho, são tipicamente 'masculinos'. A divisão sexual do trabalho estabelece a destinação prioritária dos homens à esfera produtiva (ou seja, ao trabalho que tem valor econômico, que produz a sociedade) e das mulheres à esfera reprodutiva (ou seja, ao trabalho que reproduz a mão de obra, como o cuidado e educação das crianças, manutenção do espaço doméstico, entre outros), criando não apenas uma divisão entre os trabalhos que são considerados de homens e de mulheres, como também uma hierarquia na qual os trabalhos tidos como masculinos têm mais valor que os tidos como femininos (Danièle KERGOAT, 2009).

Segundo Bourdieu (2015), "se tantas posições dificilmente são ocupadas por mulheres é porque elas são talhadas sob medida para homens cuja virilidade mesma se construiu como oposta às mulheres tais como elas são hoje" (p. 78), ou seja, profissões e sujeitos são talhados, de modo que o que é considerado necessário para determinado ofício ou cargo está intimamente relacionado a características ditas masculinas, o mesmo ocorrendo com os sujeitos e carreiras ditas femininas, sendo que, a todo o momento, essa construção é lembrada e reiterada nos discursos de pais, professores, orientadores, colegas. Assim é que, como afirma Silvia Federici (2017), a divisão sexual do trabalho redefine a posição das mulheres na sociedade e frente aos homens ao designar a elas atividades socialmente necessárias, mas desvalorizadas, invisibilizadas, consideradas como não trabalho, ficando os homens responsáveis pelo trabalho produtivo, para o mercado, único considerado gerador de valor. Essa divisão está presente na escolarização e na formação profissional, já que, apesar de haver paridade de sexo nas matrículas nos diferentes níveis de escolaridade no Brasil, as oportunidades de aprendizagem e desenvolvimento são restritas por valores androcêntricos e sexistas e noções estereotipadas de papéis sociais e identidades dicotômicas entre homens e mulheres (Maria CARVALHO; Glória RABAY, 2015). É essa realidade iníqua, que restringe seu desenvolvimento pleno e seu acesso a espaços de maior reconhecimento e valor social, que as Ovelhas Negras denunciam.

Mesmo com esta importante crítica, a visão inicial do Coletivo sobre o que é 'ser' mulher estava ancorada em uma noção universalizante e homogeneizante da categoria mulher, bem como dos feminismos e do que significa ser feminista. Seu foco estava principalmente nas iniquidades de gênero, ainda sem considerar sua intersecção com outros marcadores sociais. Com isso, não queremos dizer que as estudantes não pensassem em termos de outras iniquidades sociais, pois elas já incluíram em suas ações discussões sobre liberdade de expressão, distribuição de renda, encarceramento em massa, entre outros temas. Entretanto, levou algum tempo para que fizessem referência a como estas problemáticas estavam relacionadas às questões de gênero.

Paulatinamente, as jovens foram complexificando sua noção do que significa se tornar mulher, passando a levar em conta que não apenas as relações de poder com base em gênero definem as condições de existência dos sujeitos, sendo importantes também outros marcadores sociais, especialmente a questão racial, que começou a ganhar visibilidade no Coletivo a partir de dois acontecimentos: a participação de algumas das estudantes em uma palestra sobre a história e a teoria de Angela Davis e a notícia da morte de Marielle Franco - sendo que ambos aconteceram no mesmo dia. Sobre esse momento, uma das integrantes do Ovelhas Negras enviou a seguinte mensagem no grupo do Coletivo no aplicativo WhatsApp:

Ontem, nós assistimos à palestra sobre a Angela Davis, negra, feminista, mulher de luta. E naquela mesma hora Marielle Franco, mulher, vereadora do Rio de Janeiro, negra, feminista, e fiscal da intervenção militar que vinha relatando abuso de poder por parte dos policiais foi assassinada com 5 tiros na cabeça e no rosto (Diário de campo, registro do dia 19/03/2018, p. 43-44). 
O termo 'mulher de luta' usado pela estudante em sua mensagem havia sido bastante usado na palestra sobre Angela Davis para se referir não só a ela, mas também a todas as mulheres que se propõem a lutar em prol de um mundo mais justo. Conhecer as figuras de Angela Davis e Marielle Franco marcou o contato das jovens com a existência do feminismo negro e suas especificidades, possibilitando a descoberta de que há diferentes feminismos, frutos da pluralidade das mulheres reais. A partir desses acontecimentos, e com a entrada de uma estudante negra para o Coletivo, a presença do reconhecimento de outras vivências dentro da categoria mulher, principalmente a questão da negritude, passou a ter mais visibilidade em seu interior, abrindo caminho para o florescimento de uma visão mais crítica e interseccional de seu próprio feminismo.

Quando as estudantes falam mais diretamente sobre o que é ser feminista, para elas, e que tipo de feminismo buscam, fica claro que elas pensam feminismo de forma ampla, sem tentar restringir o termo. Apresentam uma visão flexível sobre os movimentos feministas, consideram que ele é para todas e todos, e que suas lutas servem para melhorar a vida de todas as pessoas. Ao mesmo tempo, entendem que 'ser' feminista não é uma tarefa fácil. $O$ trecho a seguir mostra isso:

A. disse que o feminismo não é algo 'entregue de bandeja' para elas, é preciso ir atrás, buscar, pesquisar, e vai ser algo incômodo. B. complementou, afirmando que dizem que o feminismo é chato (no sentido de que causa muito incômodo, atrapalha certas coisas), e as pessoas têm razão nesse ponto, pois ele é mesmo, precisa ser (Diário de campo, registro do dia 20/03/2018, p. 49).

Ao dizer que o feminismo não é 'entregue de bandeja' a elas, a estudante mostra que a aproximação com as ideias feministas vai na contramão do pensamento vigente, exige uma postura ativa, de busca e questionamento. Elas entendem que a desacomodação e o conflito - seja interno, com suas próprias certezas, seja com os outros e as imposições sociais fazem parte do feminismo e do ser feminista. Acreditamos que este entendimento do feminismo como incômodo está intimamente relacionado às experiências do Coletivo de confronto com discursos dominantes ao longo de sua trajetória, especialmente na escola e na família. Está relacionado, também, à descoberta de si próprias enquanto feministas, das contradições e transformações em seus próprios discursos e práticas, uma construção que não é tranquila, que exige autorreflexão e autocrítica constantes.
A: As pessoas soltam algumas coisas, talvez não é nem...
$B:$ É que é muito naturalizado, né.
A: É tipo, solta, às vezes até nós.
C: $\hat{E}$, às vezes até nós.
A: É uma pena, mas é tão..
B: É tão naturalizado.
$D$ : Mas é interessante que notem que a gente pense sobre isso e veja que é errado. Pra gente não só dizer "ah, ok, acontece".
Várias:
B: Nossa, às vezes eu paro, às vezes tu pensa alguma coisa, sabe, aí tu fica tipo... sabe, quando tu mesmo se... "não, pelo amor de deus, tu não pensou isso! Psh, esquece"...
D: Uhum...
B: ...e é muito bom reconhecer isso (Registro de diálogo no encontro de sistematização de experiências).

Neste diálogo, vemos o reconhecimento das jovens de que ser feminista não significa estar livre de pensamentos marcados por machismo e por sexismo, mas sim avaliar constantemente suas próprias ideias e discursos sob o crivo da busca pela equidade. Elas demonstram que estão atentas às formas como as visões de mundo dominantes estão inscritas em suas próprias subjetividades. Ser feminista, para elas, não significa estar livre de reproduzir certos discursos e práticas discriminatórias, mas, sim, estar disposta/o a reconhecer e a refletir sobre estes discursos internalizados.

Esse processo descreve uma constante transformação do Coletivo participante e de suas integrantes. Entendemos, a partir do que diz Arruda (2002), que os sujeitos não só transformam o objeto de representação, incluindo-o em seu repertório, mas também transformam a si mesmos no processo de elaboração. Assim, ao colocar o feminismo em seu cotidiano, as jovens participantes transformam não apenas os sentidos dos termos e debates feministas, incorporando a eles suas particularidades, como transformam a si mesmas. Algumas das estudantes, principalmente as que já estão há mais tempo no Coletivo, relataram que têm estudado muito, individualmente, sobre os diferentes feminismos. Assim, elas procuram formas de se posicionar, buscando como diferentes vertentes feministas propõem diferentes debates, aprofundando gradualmente suas reflexões e suas ações. Principalmente estas integrantes mais 'antigas' do movimento expressam a noção de que um coletivo feminista precisa ir além do discurso individualista e do 
empoderamento egoísta e autocentrado, devendo se voltar para a transformação da realidade social, pois entendem que é isto que significa construir um movimento político.

\section{Consideraçōes finais}

A partir dos três campos culturais delimitados para a análise - sororidade, controle dos corpos/sexualidade e 'ser' mulher/'ser' feminista -, foi possível fazer uma aproximação aos saberes e práticas produzidos pelas jovens do Coletivo. Suas representações foram criadas por meio das pautas presentes no campo feminista, ancoradas em suas vivências e necessidades cotidianas reais - processo que faz parte da construção de representações sociais, já que estas são contextuais e exercem sua função na medida em que são úteis aos sujeitos que as produzem.

A noção de sororidade, por exemplo, ao ser delimitada pelo contexto das jovens, é ancorada na busca por uma solução para as disputas e os julgamentos que marcam muitas das relações entre mulheres, especialmente no ambiente escolar. Esta percepção, aliada a uma visão interseccional e crítica, é uma ferramenta potente para a luta feminista. Quanto à questão ligada ao controle dos corpos e sexualidades, houve a produção de saberes e práticas a partir de um recorte de classe, raça e faixa etária, que partiu de exemplos distantes/gerais até os mais específicos, ligados ao contexto imediato em seus espaços de convivência, como na escola, na família e na cidade.

Por último, observamos como a noção do que é 'ser' mulher no Coletivo parece ter se transformado ao longo do tempo, se tornando mais ampla e considerando as várias possibilidades de existência dentro deste conceito, principalmente em sua interseccionalidade com a questão racial, ratificando a proposição de Beauvoir (1967) de que se tornar mulher é um processo. Ao afirmar que o feminismo não é 'entregue de bandeja' - expressão coloquial usada com sentido de entregar algo sem pedir nada em troca, sem discussão -, as jovens se referem não apenas às dificuldades que enfrentam ao criar um coletivo feminista em um espaço interiorano, tradicionalmente conservador, como também às próprias desacomodações e incômodos internos que as discussões feministas geram.

Nesse sentido, entendemos que, mesmo que nem sempre os feminismos circulantes nas redes sociais possam ser descritos como críticos, podendo sofrer inclusive esvaziamentos pela urgência dos debates feitos nestes espaços (RIBEIRO, 2017), eles possuem um potencial inegável para alcançar parcelas significativas de populações locais e para provocar a ação. Coletivos como o Ovelhas Negras são espaços potenciais para construção de conhecimento por parte das/os jovens sobre si e sobre o mundo que as/os cerca, mas, acima de tudo, são espaços de resistência coletiva 'suada', já que a ocupação desses espaços não é entregue de bandeja.

\section{Referências}

ALEMANY, Carme. "Assédio sexual". In: HIRATA, Helena; LABORIE, Françoise; LE DOARÉ, Hélène; SENOTIER, Danièle (Orgs.). Dicionário crítico do feminismo. São Paulo: EDUNESP, 2009. p. 25-29.

ALVAREZ, Sonia E. "Para além da sociedade civil: reflexões sobre o campo feminista". Cad. Pagu, Campinas, n. 43, p. 13-56, dez. 2014. Disponível em http://www.scielo.br/scielo.php?script=sci arttext\&pid=S0104-83332014000200013\&lng=en\&nrm=iso. Acesso em 15/05/2019.

ARRUDA, Angela. "Despertando do pesadelo: a interpretação". In: SOUSA, Clarilza P. et al. (Orgs.). Angela Arruda e as representações sociais: estudos selecionados. Curitiba: Champagnat; São Paulo: Fundação Carlos Chagas, 2014. p. 117-145.

ARRUDA, Angela. "Teoria das Representações Sociais e teorias de gênero". Cadernos de Pesquisa, n. 117, nov. 2002. Disponível em http://www.scielo.br/scielo.php?pid=\$0100$15742002000300007 \&$ script=sci_abstract\&tIng=pt. Acesso em 15/05/2019.

BEAUVOIR, Simone de. O Segundo Sexo: A experiência vivida. 2. ed. São Paulo: Difusão Européia do Livro, 1967.

BOURDIEU, Pierre. A Dominação Masculina. Tradução de Maria Helena Kuhner. 13. ed. Rio de Janeiro: Bertrand Brasil, 2015.

BRANDÃO, Carlos R. "A pesquisa participante e a participação da pesquisa. Um olhar entre tempos e espaços a partir da América Latina". In: BRANDÃO, Carlos R.; STRECK, Danilo R. (Orgs.). A Pesquisa Participante: o Saber da Partilha. Aparecida-SP: Ideias e Letras, 2006. p. 21-54.

BRITO, Priscilla C. de S. "Primavera Feminista: a internet e as manifestações de mulheres em 2015 no Rio de Janeiro”. In: SEMINÁRIO INTERNACIONAL FAZENDO GÊNERO 11 \& 13 TH WOMEN'S WORLDS 
CONGRESS. Anais Eletrônicos, Florianópolis, 2017. Disponível em http://www.en.wwc2017.eventos. dype.com.br/resources/anais/1499450296 ARQUIVO PrimaveraFeminista-ainterneteasmanifesta coesdemulheresem2015noRiodeJaneiro-FazendoGenero.pdf. Acesso em 15/05/2019.

BUITONI, Dulcilia S.; LOPES, Martha. "'Revista AzMina' e Carnaval sem Assédio: uma análise do jornalismo ativista no combate à violência contra a mulher". Cadernos de Gênero e Diversidade, v. 4, n. 2, abr./jun. 2018. Disponível em https://portalseer.ufba.br/index.php/cadgendiv/article/ view/24613. Acesso em 15/05/2019.

CARVALHO, Maria E. P. de; RABAY, Glória. "Usos e incompreensões do conceito de gênero no discurso educacional no Brasil". Revista Estudos Feministas, Florianópolis, v. 23, n. 1, p. 119-136, jan.-abr. 2015. Disponível em http://www.scielo.br/scielo.php?script=sci_arttext\&pid=\$0104-

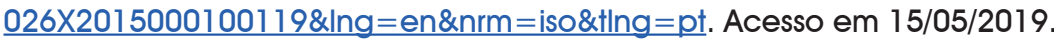

COSTA, Suely G. 'Onda, rizoma e 'sororidade' como metáforas: representações de mulheres e dos feminismos (Paris, Rio de Janeiro: anos 70/80 do século XX)". R. Inter. Interd. INTERthesis, Florianópolis, v. 6, n. 2, p. 01-29, jul./dez. 2009. Disponível em https://periodicos.ufsc.br/index.php/ interthesis/article/view/12107. Acesso em 15/05/2019.

FEDERICI, Silvia. Calibã e a bruxa: mulheres, corpo e acumulação primitiva. Tradução do Coletivo Sycorax. 1. ed. São Paulo: Elefante, 2017.

FERREIRA, Gleidiane de S. "Feminismo e redes sociais na Marcha das Vadias no Brasil". Revista Ártemis, v. XV, n. 1, p. 33-43, jan.-jul. 2013. Disponível em http://www.periodicos.ufpb.br/index. php/artemis/article/view/16636. Acesso em 15/05/2019.

GARCIA, Sergio. Margareth Rago: "O feminismo está na moda. Virou pop". Revista Época (online), 15/11/2015. Disponível em https://epoca.globo.com/vida/noticia/2015/11/margareth-rago-ofeminismo-esta-na-moda-virou-pop.html. Acesso em 22/08/2017.

GEERTZ, Clifford. "Uma descrição densa: por uma teoria interpretativa da cultura". In: GEERTZ, Clifford. A interpretação das culturas. 1. ed., 13. reimpr. Rio de Janeiro: LTC, 2008. p. 3- 21.

GONÇALVES, Eliane. "Renovar, inovar, rejuvenescer: processos de transmissão, formação e permanência no feminismo brasileiro entre 1980-2010". Revista Brasileira de Sociologia, v. 4, n. 7, jan./jun. 2016. Disponível em http://www.sbsociologia.com.br/revista/index.php/RBS/article/ view/160. Acesso em 15/05/2019.

GONÇALVES, Eliane; FREITAS, Fátima R. A.; OLIVEIRA, Elismênnia A. "Das idades transitórias: as 'jovens' no feminismo brasileiro contemporâneo, suas ações e seus dilemas". Rev. Feminismos, v. 1, n. 3, set./ dez. 2013. Disponível em https://portalseer.ufba.br/index.php/feminismos/article/view/29994/17736 e https://doaj.org/toc/2d497a0b108b43e49377f98caecf5e0e. Acesso em 15/05/2019.

GUARESCHI, Pedrinho. "Representações Sociais, Mídia e Movimentos Sociais". In: GUARESCHI, Pedrinho; HERNANDEZ, Aline; CÁRDENAS, Manuel. Representações Sociais em Movimento: psicologia do ativismo políitico. Porto Alegre: EDIPUCRS, 2010. p. 77-91.

GUZZO, Morgani. Corpos e campos plurais: os feminismos das Marchas das Vadias no Brasil (2011-2017). 2019. Doutorado (Programa de Pós-Graduação Interdisciplinar em Ciências Humanas) - Universidade Federal de Santa Catarina, Florianópolis, SC, Brasil.

HESS, Remi. "Momento do diário e diário dos momentos". In: SOUZA, Elizeu C.; ABRAHÃO, Maria Helena M. B. (Orgs.). Tempos, narrativas e ficções: a invenção de si. Dados eletrônicos. Porto Alegre: EDIPUCRS; Salvador: EDUNEB, 2006. p. 89-103.

HOLLIDAY, Oscar Jara. "Sistematização das experiências: algumas apreciações". In: BRANDÃO, Carlos R.; STRECK, Danilo R. (Orgs.). A Pesquisa Participante: o Saber da Partilha. Aparecida-SP: Ideias e Letras, 2006. p. 227-243.

hooks, bell. O feminismo é para todo mundo: políiticas arrebatadoras. 4. ed. Rio de Janeiro: Rosa dos Tempos, 2019a.

hooks, bell. Teoria feminista: da margem ao centro. 1. ed. São Paulo: Perspectiva, 2019b.

JOVCHELOVITCH, Sandra. "Representações sociais e polifasia cognitiva: notas sobre a pluralidade e sabedoria da razão". In: ALMEIDA, Angela M. de O.; SANTOS, Maria de F. de S.; TRINDADE, Zeidi A. (Orgs.). Teoria das representações sociais - 50 anos. Brasília: Technopolitik, 2014. p. 211-237. 
KERGOAT, Danièle. "Divisão sexual do trabalho e relações sociais de sexo". In: HIRATA, Helena; LABORIE, Françoise; LE DOARÉ, Hélène; SENOTIER, Danièle (Orgs.). Dicionário crítico do feminismo. São Paulo: EDUNESP, 2009. p. 67-75.

LOURO, Guacira L. "Pedagogias da Sexualidade”. In: LOURO, Guacira L. (Org.). O Corpo Educado: pedagogias da sexualidade. Tradução de Tomaz Tadeu da Silva 2. ed., 2. reimpressão. Belo Horizonte: Autêntica, 2003. p. 07-34.

LOURO, Guacira L. Gênero, Sexualidade e Educação: uma perspectiva pós-estruturalista. 6. ed. Petrópolis: Vozes, 1997.

LOVELL, Kera. "Girls Are Equal Too: Education, Body Politics, and the Making of Teenage Feminism". Gend. Issues, v. 33, n. 2, p. 71-95, 2016.

MARKOVÁ, Ivana. "A Fabricação da Teoria das Representações Sociais". Cadernos de Pesquisa, São Paulo, v. 47, n. 163, p. 358-375, mar. 2017. Disponível em http://www.scielo.br/scielo.php?script=sci arttext\&pid=S0100-15742017000100358\&lng=en\&nrm=iso. Acesso em 15/05/2019.

MEDEIROS, Fernanda L. S. "Feminismo e neoliberalismo na contemporaneidade: uma 'nova razão' para o movimento de liberação das mulheres?". Teoria e Pesquisa: Revista de Ciência Política, v. 26, n. 2, p. 146-167, 2017. Disponível em http://www.teoriaepesquisa.ufscar.br/index. php/tp/article/view/613. Acesso em 29/08/2020.

MORESCO, Marcielly C. "'Vai ter shortinho, sim': um ensaio sobre biopoder e feminismo popular na escola". In: XI ANPED SUL, Curitiba, PR. Anais... Setor de Educação da UFPR, 2016. Disponível em http://www.anpedsul2016.ufpr.br/portal/wp-content/uploads/2015/1 1/eixo18 MARCIELLY-CRISTINAMORESCO.pdf. Acesso em 15/05/2019.

MOSCOVICl, Serge. Representações Sociais: investigações em psicologia social. 11. ed. Petrópolis: Vozes, 2015.

MOSCOVICl, Serge. A psicanálise, sua imagem e seu público. Petrópolis: Vozes, 2012.

PETCHESKY, Rosalind. "Owning and Disowning the Body: a Reflection". In: BAKSH, Rawwida; HARCOURT, Wendy (Eds.). The Oxford Handbook of Transnational Feminist Movements. Oxford: Oxford University Press, 2015.

PILCHER, Jane; WHELEHAN, Imelda. Fifty Key Concepts in Gender Studies. London: Sage Publications, 2004.

REAL, Danielly da C. V. Primavera Secundarista: engajamento estudantil nas ocupações de Vitória - ES em 2016. 2018. Mestrado - Universidade Federal do Espírito Santo, Vitória, ES.

RIBEIRO, Djamila. O que é lugar de fala? Belo Horizonte: Letramento; Justificando, 2017.

ROSO, Adriane. "Mulheres Latinas e Transmissão Vertical do HIV: Visão dos Profissionais da Saúde que Atendem Mulheres Soropositivas nos Estados Unidos". Revista Interamericana de Psicología, v. 44, n. 2, p. 332-341, 2009. Disponível em https://www.redalyc.org/articulo.oa?id=28420641014 Acesso em 02/03/2018.

ROSO, Adriane; ROMANINI, Moisés. "Empoderamento individual, empoderamento comunitário e conscientização: um ensaio teórico". Psicologia e Saber Social, v. 3, n. 1, p. 83-95, 2014. Disponível em https://www.e-publicacoes.ueri.br/index.php/psi-sabersocial/article/view/12203. Acesso em 04/03/2019

RUBIN, Gayle. O Tráfico de Mulheres: notas sobre a "economia política" do sexo. Recife, PE: S.O.S. Corpo, 1993. Disponível em https://repositorio.ufsc.br/xmlui/handle/123456789/1919. Acesso em 07/05/2017.

SANTINI, Rose M.; TERRA, Camyla; ALMEIDA, Alda R. D. "Feminismo 2.0: mobilização das mulheres no Brasil contra o assédio sexual através das mídias sociais (\#primeiroassedio)". P2P e inov., Rio de Janeiro, v. 3, n. 1, set./mar. 2017. Disponível em http://revista.ibict.br/p2p/article/view/2341/2390. Acesso em 15/05/2019.

SILVA, Maria O. da S. e. "Reconstruindo um processo participativo na produção do conhecimento: uma concepção e uma prática". In: BRANDÃO, Carlos R.; STRECK, Danilo R. (Orgs.). A Pesquisa Participante: o Saber da Partilha. Aparecida-SP: Ideias e Letras, 2006. p. 123-149. 
SOUSA, Renata F. "Cultura do Estupro: prática e incitação à violência sexual contra mulheres". Revista Estudos Feministas, Florianópolis, v. 25, n. 1, p. 9-29, jan./abr. 2017. Disponível em http:/l www.scielo.br/scielo.php?script=sci_arttext\&pid $=\$ 0104-026 \times 2017000100009 \& \mathrm{lng}=$ en\& $\mathrm{nrm}=$ iso \&tlng=pt. Acesso em 15/05/2019.

STAERKLÉ, Christian; CLÉMENCE, Alain; SPINI, Dario. "Social Representations: A Normative and Dynamic Intergroup Approach". Political Psychology, v. 32, n. 5, 201 1. Disponível em https://www. istor.org/stable/41262943?seq=1\#page_scan tab_contents. Acesso em 15/05/2019.

Vanessa Soares de Castro (vanessa.castro@ibiruba.ifrs.edu.br) é psicóloga, mestra em Psicologia pelo Programa de Pós-Graduação em Psicologia da Universidade Federal de Santa Maria (UFSM), psicóloga do setor de Assistência Estudantil do IFRS campus Ibirubá, coordenadora do Núcleo de Estudos e Pesquisas em Gênero e Sexualidade (NEPGS) do IFRS campus Ibirubá.

Adriane Roso (adriane.roso@ufsm.br) é psicóloga, doutora em Psicologia (PUCRS), com pós-doutorado em Comunicação (UFSM) e Psicologia Social (Harvard University). Professora Associada na Universidade Federal de Santa Maria - UFSM. Lidera o VIDAS - Núcleo de Pesquisa, Ensino e Extensão em Psicologia Clínica Social e o Grupo de Pesquisa Saúde, Minorias Sociais e Comunicação.

Camila dos Santos Gonçalves (camila.gon.79@gmail.com) é psicóloga com Mestrado em Psicologia, área de concentração Psicologia da Saúde (UFSM). Doutorado em Psicologia Social e Institucional (UFRGS). Foi docente do Curso de Psicologia da Universidade Franciscana - UFN e Tutora no Programa de Residência Multiprofissional em Atenção Clínica Especializada (UFN). Pesquisadora e Colaboradora do VIDAS - Núcleo de Pesquisa, Ensino e Extensão em Psicologia Clínica Social e o Grupo de Pesquisa Saúde, Minorias Sociais e Comunicação. 
COMO CITAR ESTE ARTIGO DE ACORDO COM AS NORMAS DA REVISTA

CASTRO, Vanessa Soares de; ROSO, Adriane; GONÇALVES, Camila dos Santos. "O feminismo não é entregue de bandeja: saberes e práticas de um Coletivo feminista estudantil". Revista Estudos Feministas, Florianópolis, v. 29, n. 2, e65655, 2021.

\section{CONTRIBUIÇĀO DE AUTORIA}

Vanessa Soares de Castro: concepção, coleta de dados, análise de dados, elaboração do manuscrito, redação.

Adriane Roso: concepção, redação, discussão de resultados, revisão e aprovação da versão final.

Camila dos Santos Gonçalves: redação, discussão de resultados, revisão e aprovação da versão final.

\section{FINANCIAMENTO}

Apoio do Instituto Federal de Educação, Ciência e Tecnologia do Rio Grande do Sul.

CONSENTIMENTO DE USO DE IMAGEM

Não se aplica.

\section{APROVAÇĀO DE COMITÊ DE ÉTICA EM PESQUISA}

A pesquisa está vinculada ao projeto guarda-chuva "Vidas Precárias no Cibermundo - Estudos Sobre Violências, Poder e Interseccionalidades dos Sistemas Hierárquicos", coordenado pela Prof. a Dr. a Adriane Roso, que foi devidamente registrado no Sistema de Informações para o Ensino (SIE), recebendo a autenticação do Gabinete de Projetos de Pesquisa (GAP) da UFSM sob o $n^{\circ} \mathrm{GAP} / \mathrm{CCSH}$ 046983. O projeto foi aprovado pelo Comitê de Ética em Pesquisa (CEP) da UFSM (CAAE: 79231217.4.0000.5346, Número do parecer: 2.415.509).

\section{CONFLITO DE INTERESSES}

Não se aplica.

\section{LICENÇA DE USO}

Este artigo está licenciado sob a Licença Creative Commons CC-BY 4.0 International. Com essa licença você pode compartilhar, adaptar, criar para qualquer fim, desde que atribua a autoria da obra.

\section{HISTÓRICO}

Recebido em 11/06/2019

Reapresentado em 25/09/2020

Aprovado em 17/02/2021 